\title{
PENILAIAN 4 DIMENSI PADA KUALITAS HIDUP PASIEN RAWAT JALAN DIABETES MELITUS TIPE II (E 14.9) DI RUMAH SAKIT UMUM ARI CANTI PERIODE 2018
}

\section{ASSESMENT OF QUALITY OF LIFE OF DIABETES MELITUS TYPE II (E 14.9) INPATIENTS IN ARI CANTI GENERAL HOSPITAL IN PERIOD OF 2018}

\author{
FITRIA MEGAWATI*, I PUTU TANGKAS SUWANTARA* \\ *Fakultas Farmasi Universitas Mahasaraswati Denpasar, Jalan Kamboja No. 11A, Denpasar, Bali
}

\begin{abstract}
Abstrak: Diabetes Melitus merupakan kondisi yang ditandai oleh hiperglikemia akibat ketidakmampuan tubuh untuk menggunakan glukosa darah untuk energi. (American Diabetes Association, 2018). Diabetes Melitus akan menyertai seumur hidup sehingga dapat mempengaruhi kualitas hidup penderita. Kualitas hidup merupakan persepsi individu mengenai posisinya dalam konteks budaya dan sistem nilai pada tempat individu tersebut hidup dan hubungannya dengan tujuan, harapan, standar dan fokus hidupnya (WHO, 2012). Penelitian ini bertujuan untuk mengetahui gambaran kualitas hidup penderita Diabetes Melitus Tipe II yang melakukan rawat jalan di Rumah Sakit Umum Ari Canti ditinjau dari 4 dimensi penilaian kualitas hidup. Jenis penelitian ini adalah penelitian deskriptif dengan desain cross sectional study. Pengambilan sampel dilakukan dengan cara consecutive sampling dan menggunakan instrument berupa kuisioner dengan 26 item pertanyaan yang dapat digunakan untuk mengukur kualitas hidup penderita DM yang diperoleh dari WHO QoL-BREF. Dari penelitian yang telah dilakukan pada 100 responden, diperoleh hasil bahwa rata-rata responden merasa kualitas hidupnya sedang serta merasa keadaan kesehatannya sedang. Ditinjau dari dimensi kesehatan fisik, dimensi psikologis, dimensi hubungan sosial dan dimensi lingkungan rata-rata responden penderita DM yang melakukan rawat jalan di Rumah Sakit Umum Ari Canti memiliki kualitas hidup yang sedang.
\end{abstract}

Kata Kunci: diabetes melitus tipe II, kualitas hidup, WHOQoL-BREF

\begin{abstract}
Diabetes mellitus is a result characterized by hyperglycemia due to the body's inability to use blood (American Diabetes Association, 2018). Diabetes mellitus will accompany quality of life which can affect the quality of life of patients. Quality of life is an individual's perception of his position in the context of culture and value systems in the place of the individual with hope, hope, standards and a broad focus (WHO, 2012). This study aims to find the quality of life for patients with Type II diabetes mellitus who are outpatient at Ari Canti General Hospital in terms of 4 dimensions of quality of life assessment. This type of research is a descriptive study with a cross sectional study design. Sampling was done by purposive sampling and using an instrument in the form of a questionnaire with 26 items of questions that can be used to measure the quality of life of DM patients obtained from the WHO QoL-BREF score category. From the research that has been conducted on 100 respondents, the results obtained on average respondents who receive the quality obtained from the general are discussing about moderate health. Judging from the dimensions of physical health, psychological dimensions, dimensions of social relations and the dimensions of the average respondent of DM patients who are outpatient at Ari Canti General Hospital have a quality of life in the moderate score category.
\end{abstract}

Keywords: diabetes mellitus type II, quality of life, WHOQoL-BREF

\section{PENDAHULUAN}

Angka kejadian penyakit tidak menular semakin meningkat di masyarakat dan menjadi perhatian. Salah satu penyakit tidak menular (PTM) adalah Diabetes Melitus (DM). Diabetes Melitus (DM) merupakan kondisi yang ditandai oleh hiperglikemia akibat ketidakmampuan tubuh untuk menggunakan glukosa darah untuk energi (American Diabetes Association, 2018).

Jumlah penderita Diabetes Melitus di dunia mengalami peningkatan dari 108 juta orang pada tahun 1980 menjadi 422 juta orang pada tahun 2014. Prevalensi global dari diabetes melitus pada orang dewasa diatas usia 18 tahun mengalami peningkatan dari tahun 1980 sebesar 4,7\% menjadi $8,5 \%$ pada tahun 2014. Berdasarkan jumlah tersebut negara Indonesia menempati urutan ke-5 terbesar di dunia (World Health Organization, 2018). Pengembangan Kesehatan Kementrian Kesehatan dengan hasil Riset Kesehatan Dasar (RISKESDAS) tahun 2018, terjadi peningkatan prevalensi pada penderita Diabetes Melitus di Indonesia dari 6,9\% (tahun 2013) menjadi 8,5\% (2018) (Riskesdas, 2018). Diabetes Melitus yang tidak terkendali dan tidak diobati dengan benar akan menjadi kronis dan berakibat pada munculnya komplikasi. Diabetes melitus dapat menyebabkan 
komplikasi akut seperti hipoglikemi dan ketoasidosis diabetik (KAD). Komplikasi kronis juga dapat terjadi apabila hiperglikemi berlangsung menahun menimbulkan penyakit kardiovaskuler, gagal ginjal, gangguan penglihatan dan sistem syaraf. Komplikasi tersebut dapat mengakibatkan pada berkurangnya usia harapan hidup penderita, kelumpuhan dan meningkatkan beban ekonomi bagi penderita beserta keluarganya (Ernawati, 2013).

Diabetes Melitus akan menyertai seumur hidup sehingga dapat mempengaruhi kualitas hidup penderita. Kualitas hidup merupakan persepsi individu mengenai posisinya dalam konteks budaya dan sistem nilai pada tempat individu tersebut hidup dan hubungannya dengan tujuan, harapan, standar dan fokus hidupnya (WHO, 2012). Hidup dengan diabetes melitus dapat berpengaruh negatif terhadap kualitas hidup penderita baik dengan atau tanpa komplikasi. Kualitas hidup pada penderita DM dapat diartikan sebagai perasaan penderita terhadap kehidupannya secara umum dan kehidupan bersama diabetes.

Konsep kualitas hidup meliputi beberapa dimensi yang kompleks dalam kehidupan individu, meliputi 4 dimensi yaitu kesehatan fisik, psikologis, hubungan sosial dan lingkungan. Yudianto dkk (2008) memaparkan sejumlah aspek dari diabetes melitus yang dapat mempengaruhi kualitas hidup antara lain, selama hidup diharuskan menjalani terapi farmakologis, pembatasan dan pengaturan diet serta monitoring gula darah; kekhawatiran apabila muncul gejala hipoglikemi maupun hiperglikemi; ketakutan mengalami komplikasi DM; dan timbulnya disfungsi seksual.

Pada era Jaminan Kesehatan Nasional $(\mathrm{JKN})$, pemerintah telah menunjuk rumah sakit sebagai sarana pelayanan dan perawatan penyakit DM. Rumah Sakit Umum Ari Canti merupakan salah satu rumah sakit swasta di Kabupaten Gianyar yang melayani pengobatan rawat jalan untuk penderita DM.

Adapun tujuan dari penelitian ini yaitu untuk mengetahui penilaian 4 dimensi pada kualitas hidup pasien rawat jalan penderita Diabetes Melitus Tipe II yang melakukan rawat jalan di Rumah Sakit Umum Ari Canti periode 2018.

\section{METODE PENELITIAN}

Penelitian ini dilakukan di Rumah Sakit Umum Ari Canti yang beralamat di Jalan Raya Mas Ubud, Kabupaten Gianyar. Penelitian dilakukan pada bulan Desember 2018 sampai Mei tahun 2019. RSU Ari Canti dipilih karena sesuai dengan kriteria inklusi yang ditetapkan peneliti yaitu berlokasi di daerah Gianyar mempunyai catatan pengobatan pasien.

Penelitian ini merupakan analisis deskriptif yang merupakan suatu metode yang digunakan untuk melihat gambaran fenomena (termasuk kesehatan) yang terjadi di dalam suatu populasi tertentu. Rancangan penelitian menggunakan desain penelitian cross sectional study, dimana pengambilan data dengan potong lintang yang dapat diartikan bahwa peneliti melakukan pengukuran atau penelitian dalam satu waktu (Notoatmodjo, 2012). Desain dan rancangan disesuaikan dengan tujuan peneliti ini yaitu untuk mengetahui gambaran kualitas hidup pasien Diabetes Melitus Tipe II di Rumah Sakit Ari Canti.

Populasi penelitian adalah seluruh pasien DM Tipe II di Rumah Sakit Umum Ari Canti yang melakukan rawat jalan. Sampel dari penelitian ini adalah:

1. Kriteria Inklusi

a. Pasien rawat jalan Diabetes Melitus Tipe II di Rumah Sakit Umum Ari Canti sejak periode 2018 yang dapat berkomunikasi dengan baik.

b. Pasien rawat jalan Diabetes Melitus Tipe II sejak periode 2018 yang telah melakukan kunjungan pengobatan ke Rumah Sakit Umum Ari Canti lebih dari 5 kali.

c. Pasien rawat jalan Diabetes Melitus Tipe II di Rumah Sakit Umum Ari Canti periode yang bersedia menjadi responden.

2. Kriteria Eksklusi

a. Pasien rawat jalan Diabetes Melitus Tipe II di Rumah Sakit Umum Ari Canti yang mengalami komplikasi penyakit lain.

b. Pasien rawat jalan Diabetes Melitus Tipe II di Rumah Sakit Umum Ari Canti yang tidak mengisi kuisioner dengan lengkap.

Jumlah sampel yang memenuhi kriteria inklusi dan eksklusi sebanyak 100 orang. Kuisioner ini dibuat dalam bentuk kuesioner yang diadopsi dari World Health Organization Quality Of Life (WHOQOL)-BREF. Pada bagian awal dari instrumen penelitian ini terdapat data demografi yang meliputi nama, jenis kelamin, umur, pendidikan terakhir, pekerjaan sebelumnya, status perkawinan dan lama kunjungan. Dilanjutkan dengan kuesioner kualitas hidup dari WHOQOLBREF yaitu pengukuran yang menggunakan 26 item pertanyaan (WHO, 2012). Dimana alat ukur ini mengunakan empat dimensi yaitu fisik, psikologis, hubungan sosial dan lingkungan. 


\section{HASIL}

\section{Karakteristik Responden}

Karakteristik responden dari 100 responden, sebagian dari responden (36\%) berumur 52-58 tahun. Sebagian besar responden (63\%) berjenis kelamin laki-laki. Sebagian besar responden (98\%) sudah menikah. Tingkat pendidikan sebagian dari responden adalah SMA (46\%). Semua responden sesuai dengan kriteria inklusi dan eksklusi.

\section{Gambaran Kualitas Hidup Responden}

1. Gambaran Umum Kualitas Hidup Penderita Diabetes Melitus Tipe II di Rumah Sakit Umum Ari Canti Periode 2019.

Berikut merupakan persentase persepsi penderita DM Tipe II terhadap kualitas hidupnya secara umum dari total skor pertanyaan nomor 1 .

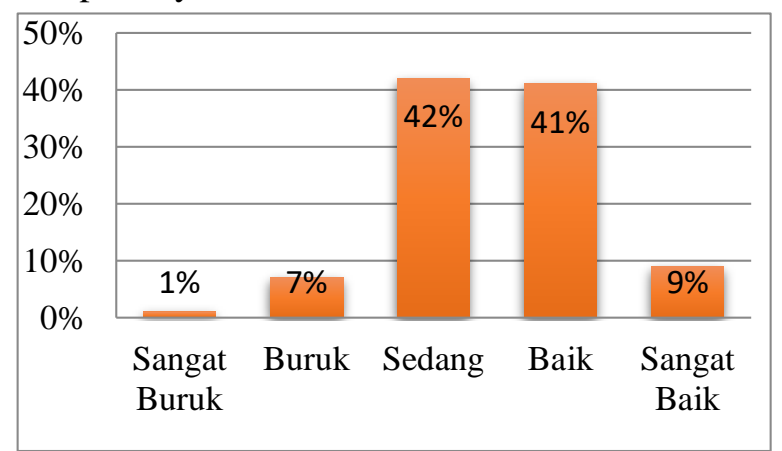

Gambar 1. Persentase Persepsi Penderita DM

Terhadap Kualitas Hidupnya Secara Umum

Gambar 1 menunjukan bahwa kualitas hidup penderita rawat jalan DM di Rumah Sakit Umum Ari Canti secara keseluruhan dari responden merasa kualitas hidupnya sedang (42\%) dan sedikit dari responden (1\%) merasa kualitas hidupnya sangat buruk. Berikut merupakan persentase persepsi penderita DM Tipe 2 terhadap kesehatannya secara umum dari total skor pertanyaan nomor 2 .

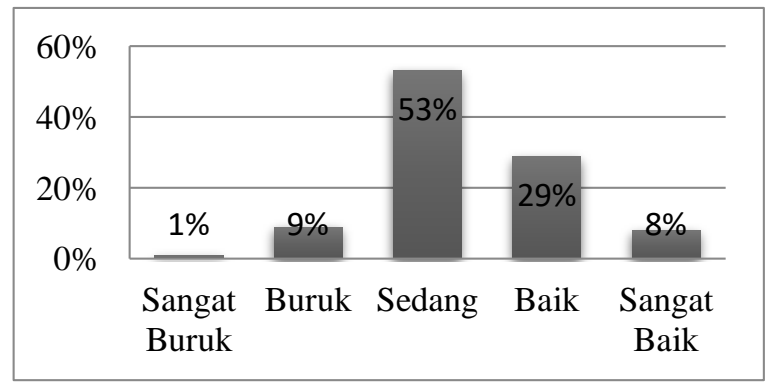

Gambar 2. Persentase Persepsi Penderita DM Terhadap Kesehatannya Secara Umum
Gambar 2 menunjukkan bahwa persepsi penderita rawat jalan DM di Rumah Sakit Umum Ari Canti terhadap kesehatannya secara umum sebagaian besar merasa status kesehatannya sedang $(53 \%)$ dan hanya sedikit dari responden yang merasa status kesehatannya sangat buruk $(1 \%)$.

2. Gambaran Kualitas Hidup Penderita Diabetes Melitus Tipe II di Rumah Sakit Umum Ari Canti Berdasarkan Dimensi Penilaian Kualitas Hidup

Gambaran Kualitas Hidup Pasien Rawat Jalan Diabetes Melitus Tipe II di Rumah Sakit Umum Ari Canti berdasarkan Dimensi Kesehatan Fisik, dapat dilihat pada tabel 2 berikut ini.

Tabel 2. Persentase Gambaran Kualitas Hidup

Pasien Rawat Jalan Diabetes Melitus Tipe II di

Rumah Sakit Umum Ari Canti dilihat dari

Dimensi Kesehatan Fisik $(n=100)$.

\begin{tabular}{ccc}
\hline $\begin{array}{c}\text { Dimensi } \\
\text { Penilaian } \\
\text { Kualitas Hidup }\end{array}$ & Kategori & Persentase \\
\hline & Sangat Buruk & $0 \%$ \\
Dimensi & Buruk & $9 \%$ \\
Kesehatan Fisik & Sedang & $53 \%$ \\
(D-1) & Baik & $34 \%$ \\
& Sangat Baik & $4 \%$ \\
\hline
\end{tabular}

Ditinjau dari dimensi kesehatan fisik sebanyak 9 orang $(9 \%)$ responden memiliki kualitas hidup yang buruk, 53 orang (53\%) responden memiliki kualitas hidup sedang, 34 orang $(34 \%)$ responden memiliki kualitas hidup yang baik dan 4 orang (4\%) responden memiliki kualitas hidup yang sangat baik.

Jika dilihat dari masing-masing aspek dalam dimensi kesehatan fisik, maka dapat dilihat pada tabel 3 berikut.

Tabel 3. Kualitas Hidup Pasien DM Tipe II di

Rumah Sakit Umum Ari Canti dilihat dari Aspek dalam Dimensi Kesehatan Fisik $(n=100)$.

\begin{tabular}{clcc}
\hline No & Item QoL & Kategori & $\begin{array}{c}\text { Persen- } \\
\text { tase }(\%)\end{array}$ \\
\hline \multirow{2}{*}{1} & Seberapa jauh & tidak sama sekali & 7 \\
& rasa sakit & sedikit & 22 \\
& mencegah & dalam jumlah sedang & 41 \\
& aktivitas & sangat sering & 29 \\
& & dalam jumlah berlebih & 1 \\
\hline \multirow{2}{*}{2} & Tergantung & tidak sama sekali & 23 \\
& pada obat- & sedikit & 26 \\
& obatan untuk & dalam jumlah sedang & 25 \\
& kehidupan & sangat sering & 23 \\
& sehari-hari & dalam jumlah berlebih & 3 \\
\hline
\end{tabular}




\begin{tabular}{|c|c|c|c|}
\hline No & Item QoL & Kategori & $\begin{array}{l}\text { Persen- } \\
\text { tase }(\%)\end{array}$ \\
\hline \multirow{5}{*}{3} & \multirow{5}{*}{$\begin{array}{l}\text { Energi untuk } \\
\text { beraktivitas } \\
\text { sehari-hari }\end{array}$} & tidak sama sekali & 13 \\
\hline & & sedikit & 33 \\
\hline & & sedang & 36 \\
\hline & & seringkali & 17 \\
\hline & & sepenuhnya dialami & 1 \\
\hline \multirow{5}{*}{4} & \multirow{5}{*}{$\begin{array}{l}\text { Melakukan } \\
\text { mobilitas } \\
\text { dalam } \\
\text { kehidupan } \\
\text { sehari-hari }\end{array}$} & sangat buruk & 3 \\
\hline & & buruk & 13 \\
\hline & & biasa-biasa saja & 53 \\
\hline & & baik & 30 \\
\hline & & sangat baik & 1 \\
\hline \multirow{5}{*}{5} & \multirow{5}{*}{$\begin{array}{l}\text { Kepuasan } \\
\text { tidur }\end{array}$} & $\begin{array}{l}\text { sangat tidak } \\
\text { memuaskan }\end{array}$ & 2 \\
\hline & & tidak memuaskan & 13 \\
\hline & & biasa-biasa saja & 45 \\
\hline & & memuaskan & 36 \\
\hline & & sangat memuaskan & 4 \\
\hline \multirow{5}{*}{6} & \multirow{5}{*}{$\begin{array}{l}\text { Kepuasan } \\
\text { dengan } \\
\text { kemampuan } \\
\text { untuk } \\
\text { menampilkan } \\
\text { aktivitas } \\
\text { sehari-hari }\end{array}$} & $\begin{array}{l}\text { sangat tidak } \\
\text { memuaskan }\end{array}$ & 1 \\
\hline & & tidak memuaskan & 29 \\
\hline & & biasa-biasa saja & 39 \\
\hline & & memuaskan & 31 \\
\hline & & sangat memuaskan & 0 \\
\hline \multirow{5}{*}{7} & \multirow{5}{*}{$\begin{array}{l}\text { Kepuasan } \\
\text { dengan } \\
\text { kemampuan } \\
\text { untuk bekerja }\end{array}$} & $\begin{array}{l}\text { sangat tidak } \\
\text { memuaskan }\end{array}$ & 0 \\
\hline & & tidak memuaskan & 10 \\
\hline & & biasa-biasa saja & 10 \\
\hline & & memuaskan & 56 \\
\hline & & sangat memuaskan & 24 \\
\hline
\end{tabular}

3. Gambaran Kualitas Hidup Pasien Rawat Jalan Diabetes Melitus Tipe II di Rumah Sakit Umum Ari Canti berdasarkan Dimensi Psikologi. Jika dilihat dari masing-masing aspek dalam dimensi keadaan psikologis, maka dapat dilihat pada tabel 4 berikut.

Tabel 4. Persentase Gambaran Kualitas Hidup Pasien Diabetes Melitus Tipe II di Rumah Sakit Umum Ari Canti dilihat dari Dimensi Psikologi $(\mathrm{n}=100)$.

\begin{tabular}{|c|c|c|}
\hline $\begin{array}{c}\text { Dimensi } \\
\text { Penilaian } \\
\text { Kualitas } \\
\text { Hidup } \\
\end{array}$ & Kategori & Persentase \\
\hline \multirow{5}{*}{$\begin{array}{l}\text { Dimensi } \\
\text { Psikologis } \\
\text { (D-2) }\end{array}$} & Sangat Buruk & $0 \%$ \\
\hline & Buruk & $5 \%$ \\
\hline & Sedang & $45 \%$ \\
\hline & Baik & $45 \%$ \\
\hline & Sangat Baik & $5 \%$ \\
\hline
\end{tabular}

Ditinjau dari dimensi psikologis sebanyak 5 orang $(5 \%)$ responden memiliki kualitas hidup yang buruk, 45 orang $(45 \%)$ responden memiliki kualitas hidup sedang, 45 orang (45\%) responden memiliki kualitas hidup yang baik dan 5 orang (5\%) responden memiliki kualitas hidup yang sangat baik.

Jika dilihat dari masing-masing aspek dalam dimensi psikologi, maka dapat dibuat distribusi rata-rata seperti pada tabel 5 berikut.

Tabel 5. Distribusi Rata-rata Kualitas Hidup

Pasien DM Tipe II di Rumah Sakit Umum Ari Canti dilihat dari Aspek dalam Dimensi Psikologi $(\mathrm{n}=100)$.

\begin{tabular}{|c|c|c|c|}
\hline No & Item Qol & Kategori & $\begin{array}{c}\text { Persen- } \\
\text { tase } \\
(\%)\end{array}$ \\
\hline \multirow{5}{*}{1} & \multirow{5}{*}{$\begin{array}{l}\text { Seberapa } \\
\text { jauh } \\
\text { menikmati } \\
\text { hidup (Bisa } \\
\text { bersyukur) }\end{array}$} & tidak sama sekali & 4 \\
\hline & & sedikit & 13 \\
\hline & & dalam jumlah sedang & 42 \\
\hline & & sangat sering & 31 \\
\hline & & dalam jumlah berlebih & 9 \\
\hline \multirow{5}{*}{2} & \multirow{5}{*}{$\begin{array}{l}\text { Seberapa } \\
\text { jauh merasa } \\
\text { hidup berarti } \\
\text { (Produktif) }\end{array}$} & tidak sama sekali & 3 \\
\hline & & sedikit & 24 \\
\hline & & dalam jumlah sedang & 36 \\
\hline & & sangat sering & 36 \\
\hline & & dalam jumlah berlebih & 1 \\
\hline \multirow{5}{*}{3} & \multirow{5}{*}{$\begin{array}{l}\text { Kemampuan } \\
\text { berkonsen- } \\
\text { trasi (Fokus } \\
\text { pada } \\
\text { aktivitas) }\end{array}$} & tidak sama sekali & 4 \\
\hline & & sedikit & 17 \\
\hline & & dalam jumlah sedang & 28 \\
\hline & & sangat sering & 47 \\
\hline & & dalam jumlah berlebih & 4 \\
\hline \multirow{5}{*}{4} & \multirow{5}{*}{$\begin{array}{l}\text { Mampu } \\
\text { menerima } \\
\text { penampilan } \\
\text { diri sendiri }\end{array}$} & tidak sama sekali & 5 \\
\hline & & sedikit & 9 \\
\hline & & sedang & 38 \\
\hline & & seringkali & 41 \\
\hline & & sepenuhnya dialami & 7 \\
\hline \multirow{5}{*}{5} & \multirow{5}{*}{$\begin{array}{l}\text { Kepuasan } \\
\text { terhadap diri } \\
\text { sendiri }\end{array}$} & sangat tidak memuaskan & 1 \\
\hline & & tidak memuaskan & 8 \\
\hline & & biasa-biasa saja & 34 \\
\hline & & memuaskan & 39 \\
\hline & & sangat memuaskan & 18 \\
\hline \multirow{5}{*}{6} & \multirow{5}{*}{$\begin{array}{l}\text { Memiliki } \\
\text { perasaan } \\
\text { negatif }\end{array}$} & tidak pernah & 49 \\
\hline & & jarang & 33 \\
\hline & & cukup sering & 14 \\
\hline & & sangat sering & 4 \\
\hline & & selalu & 0 \\
\hline
\end{tabular}

4. Gambaran Kualitas Hidup Pasien Rawat Jalan Diabetes Melitus Tipe II di Rumah Sakit Umum Ari Canthi berdasarkan Dimensi Hubungan Sosial.

Jika dilihat dari masing-masing aspek dalam dimensi Hubungan Sosial, maka dapat dilihat pada tabel 6 berikut. 
Tabel 6. Persentase Gambaran Kualitas Hidup Pasien Diabetes Melitus Tipe II di Rumah Sakit Umum Ari Canti dilihat dari Dimensi Hubungan Sosial $(n=100)$.

\begin{tabular}{ccc}
\hline $\begin{array}{c}\text { Dimensi } \\
\text { Penilaian } \\
\text { Kualitas } \\
\text { Hidup }\end{array}$ & Kategori & Persentase \\
\hline Dimensi & Sangat Buruk & \\
Hubungan & Buruk & $8 \%$ \\
Sosial & Sedang & $45 \%$ \\
(D-3) & Baik & $41 \%$ \\
& Sangat Baik & $6 \%$ \\
\hline
\end{tabular}

Ditinjau dari dimensi hubungan sosial sebanyak 8 orang $(8 \%)$ responden memiliki kualitas hidup yang buruk, 45 orang (45\%) responden memiliki kualitas hidup sedang, 41 orang $(41 \%)$ responden memiliki kualitas hidup yang baik dan 6 orang (6\%) responden memiliki kualitas hidup yang sangat baik.

Jika dilihat dari masing-masing aspek dalam dimensi hubungan sosial, maka dapat dibuat distribusi rata-rata seperti pada tabel 7 berikut:

Tabel 7. Distribusi Rata-rata Kualitas Hidup Pasien DM Tipe II di Rumah Sakit Umum Ari

Canti dilihat dari Aspek dalam Dimensi Hubungan Sosial $(\mathrm{n}=100)$.

\begin{tabular}{|c|c|c|c|}
\hline No & Item QoL & Kategori & $\begin{array}{l}\text { Persen- } \\
\text { tase (\%) }\end{array}$ \\
\hline \multirow{5}{*}{1} & \multirow{5}{*}{$\begin{array}{l}\text { Kepuasan } \\
\text { terhadap } \\
\text { hubungan } \\
\text { personal atau } \\
\text { social }\end{array}$} & $\begin{array}{l}\text { Sangat tidak } \\
\text { memuaskan }\end{array}$ & 2 \\
\hline & & Tidak memuaskan & 12 \\
\hline & & Biasa-biasa saja & 28 \\
\hline & & Memuaskan & 42 \\
\hline & & Sangat memuaskan & 16 \\
\hline \multirow{5}{*}{2} & \multirow{5}{*}{$\begin{array}{l}\text { Kepuasan } \\
\text { terhadap } \\
\text { kehidupan } \\
\text { seksual }\end{array}$} & $\begin{array}{l}\text { Sangat tidak } \\
\text { memuaskan }\end{array}$ & 0 \\
\hline & & Tidak memuaskan & 13 \\
\hline & & Biasa-biasa saja & 24 \\
\hline & & Memuaskan & 48 \\
\hline & & Sangat memuaskan & 15 \\
\hline \multirow{5}{*}{3} & \multirow{5}{*}{$\begin{array}{l}\text { Kepuasan } \\
\text { terhadap } \\
\text { dukungan } \\
\text { sosial yang } \\
\text { diperoleh }\end{array}$} & $\begin{array}{l}\text { Sangat tidak } \\
\text { memuaskan }\end{array}$ & 0 \\
\hline & & Tidak memuaskan & 10 \\
\hline & & Biasa-biasa saja & 10 \\
\hline & & Memuaskan & 56 \\
\hline & & Sangat memuaskan & 24 \\
\hline
\end{tabular}

5. Gambaran Kualitas Hidup Pasien Rawat Jalan Diabetes Melitus Tipe II di Rumah Sakit Umum Ari Canti berdasarkan Dimensi Lingkungan.

Jika dilihat dari masing-masing aspek dalam dimensi Lingkungan, maka dapat dilihat pada tabel 8 berikut.
Tabel 8. Persentase Gambaran Kualitas Hidup Pasien Diabetes Melitus Tipe II di Rumah Sakit Umum Ari Canti dilihat dari Dimensi Lingkungan $(n=100)$.

\begin{tabular}{|c|c|c|}
\hline $\begin{array}{c}\text { Dimensi } \\
\text { Penilaian } \\
\text { Kualitas } \\
\text { Hidup }\end{array}$ & Kategori & Persentase \\
\hline \multirow{5}{*}{$\begin{array}{l}\text { Dimensi } \\
\text { Lingkungan } \\
\text { (D-4) }\end{array}$} & Sangat Buruk & $0 \%$ \\
\hline & Buruk & $6 \%$ \\
\hline & Sedang & $46 \%$ \\
\hline & Baik & $45 \%$ \\
\hline & Sangat Baik & $3 \%$ \\
\hline
\end{tabular}

Ditinjau dari dimensi lingkungan sebanyak 6 orang $(6 \%)$ responden memiliki kualitas hidup yang buruk, 46 orang $(46 \%)$ responden memiliki kualitas hidup sedang, 45 orang $(45 \%)$ responden memiliki kualitas hidup yang baik dan 3 orang (3\%) responden memiliki kualitas hidup yang sangat baik.

Jika dilihat dari masing-masing aspek dalam dimensi hubungan sosial, maka dapat dibuat distribusi rata-rata seperti pada tabel 9 berikut.

Tabel 9. Distribusi Rata-rata Kualitas Hidup

Pasien DM Tipe II di Rumah Sakit Umum Ari

Canti dilihat dari Aspek dalam Dimensi Lingkungan $(\mathrm{n}=100)$.

\begin{tabular}{|c|c|c|c|}
\hline No & Item Qol & Kategori & $\begin{array}{l}\text { Persen- } \\
\text { tase }(\%)\end{array}$ \\
\hline \multirow{5}{*}{1} & \multirow{5}{*}{$\begin{array}{l}\text { Merasa aman } \\
\text { sehari-hari }\end{array}$} & Tidak sama sekali & 1 \\
\hline & & Sedikit & 17 \\
\hline & & Dalam jumlah sedang & 52 \\
\hline & & Sangat sering & 26 \\
\hline & & Dalam jumlah berlebih & 4 \\
\hline \multirow{5}{*}{2} & \multirow{5}{*}{$\begin{array}{l}\text { Kesehatan } \\
\text { lingkungan } \\
\text { tempat tinggal }\end{array}$} & Tidak sama sekali & 4 \\
\hline & & Sedikit & 13 \\
\hline & & Dalam jumlah sedang & 42 \\
\hline & & Sangat sering & 32 \\
\hline & & Dalam jumlah berlebih & 9 \\
\hline \multirow{5}{*}{3} & \multirow{5}{*}{$\begin{array}{l}\text { Kemampuan } \\
\text { untuk } \\
\text { memenuhi } \\
\text { kebutuhan }\end{array}$} & Tidak sama sekali & 6 \\
\hline & & Sedikit & 10 \\
\hline & & Sedang & 59 \\
\hline & & Seringkali & 22 \\
\hline & & Sepenuhnya dialami & 3 \\
\hline \multirow{5}{*}{4} & \multirow{5}{*}{$\begin{array}{l}\text { Ketersediaan } \\
\text { Informasi bagi } \\
\text { kehidupan } \\
\text { sehari-hari }\end{array}$} & Tidak sama sekali & 4 \\
\hline & & Sedikit & 21 \\
\hline & & Sedang & 27 \\
\hline & & Seringkali & 48 \\
\hline & & Sepenuhnya dialami & 0 \\
\hline \multirow{5}{*}{5} & \multirow{5}{*}{$\begin{array}{l}\text { Kesempatan } \\
\text { untuk } \\
\text { melakukan } \\
\text { rekreasi di } \\
\text { waktu luang }\end{array}$} & Tidak sama sekali & 13 \\
\hline & & Sedikit & 33 \\
\hline & & Sedang & 36 \\
\hline & & Seringkali & 17 \\
\hline & & Sepenuhnya dialami & 1 \\
\hline \multirow{5}{*}{6} & \multirow{5}{*}{$\begin{array}{l}\text { Kepuasan } \\
\text { lingkungan } \\
\text { tempat tinggal }\end{array}$} & Sangat tidak memuaskan & 1 \\
\hline & & Tidak memuaskan & 8 \\
\hline & & Biasa-biasa saja & 34 \\
\hline & & Memuaskan & 39 \\
\hline & & Sangat memuaskan & 18 \\
\hline
\end{tabular}




\begin{tabular}{clcc}
\hline No & Item Qol & Kategori & $\begin{array}{c}\text { Persen- } \\
\text { tase (\%) }\end{array}$ \\
\hline \multirow{2}{*}{7} & Kepuasan akses & Sangat tidak memuaskan & 2 \\
& layanan & Tidak memuaskan & 12 \\
& kesehatan & Biasa-biasa saja & 28 \\
& & Memuaskan & 42 \\
& & Sangat memuaskan & 16 \\
\hline \multirow{2}{*}{8} & Kepuasan & Sangat tidak memuaskan & 0 \\
& sarana & Tidak memuaskan & 13 \\
& transportasi & Biasa-biasa saja & 24 \\
& & Memuaskan & 48 \\
\hline
\end{tabular}

\section{PEMBAHASAN}

Berdasarkan hasil penelitian yang dilakukan pada 100 responden penderita DM Tipe II yang melakukan rawat jalan di Rumah Sakit Umum Ari Canti, didapatkan hasil penderita DM tipe II berdasarkan usia, jenis kelamin, pekerjaan dan status pernikahan. Sampel dalam penelitian ini adalah pasien rawat jalan yang melakukan kunjungan lebih dari 5 kali. Karakteristik responden merupakan faktor penunjang dalam penelitian.

Usia seseorang mempengaruhi kualitas hidup dimana semakin tua umur seseorang juga akan semakin menurun kualitas hidup seseorang. Teori mengungkapkan bahwa Diabetes Melitus Tipe II adalah jenis diabetes yang lebih banyak jumlahnya yaitu $90-95 \%$ dari semua penderita Diabetes Melitus dan banyak dialami oleh orang dewasa yang berusia diatas 40 tahun. Hal ini diakibatkan karena resistensi insulin pada Diabetes Melitus Tipe II cenderung lebih meningkat pada lansia yang berusia 40-65 tahun (Smeltzer \&Bare, 2008). Kemampuan diri dapat menurun seiring dengan bertambahnya umur. Dampak dari penurunan fungsi tubuh dapat berpengaruh pada keberhasilan manajemen diabetes yang akan berakibat munculnya gangguan kesehatan sehingga berpengaruh terhadap kualitas hidup pasien Diabetes Melitus Tipe II (Herdianti, 2017). Berdasarkan hasil penelitian yang dilakukan pada penderita Diabetes Melitus Tipe II yang melakukan rawat jalan di Rumah Sakit Umum Ari Canti, penderita DM Tipe II berdasarkan usia, paling banyak diderita oleh responden 45 tahun ke atas. Hal ini sejalan dengan hasil penelitian yang di bahas dalam beberapa penelitian ilmiah yang sudah dijelaskan bahwa penderita Diabetes Melitus banyak dialami oleh orang dewasa yang berusia diatas 40 tahun. Hal ini diakibatkan karena pada usia 40 tahun terjadi perubahan fungsi dan anatomi tubuh yang dapat menyebabkan berbagai masalah seperti psikologi, sosial, fisik, dan menimbulkan keterbatasan yang dapat berpengaruh pada kualitas hidup.

Kualitas hidup (QoL) yang rendah juga signifikan berhubungan dengan tingkat pendidikan yang rendah dan kebiasaan aktifitas fisik yang kurang baik (Gautama et al 2009 dalam Silaban, 2013). Menurut Stipanovic (2002 dalam Silaban, 2013) menyatakan pendidikan merupakan faktor yang penting pada pasien DM untuk dapat memahami dan mengatur dirinyasendiri. Berdasarkan penelitian yang dilakukan pada penderita Diabetes Melitus Tipe II yang melakukan rawat jalan di Rumah Sakit Umum Ari Canti pendidikan responden sebagian besar Sekolah Menengah Atas (SMA) $46 \%$, kemudian dilanjutkan dengan Sekolah Dasar (SD) 18\%, Perguruan tinggi $21 \%$ dan terakhir SMP yaitu 9\% dan tidak bersekolah sebanyak 6 orang.

Berdasarkan hasil penelitian yang dilakukan pada penderita Diabetes Melitus Tipe II yang melakukan rawat jalan di Rumah Sakit Umum Ari Canti, penderita DM Tipe II berdasarkan usia Jenis kelamin responden mayoritas perempuan $63 \%$ sedangkan laki-laki sebanyak 37\%. Hal ini tidak sejalan dengan penelitian yang dilakukan Gautam dkk (2009) bahwa kualitas hidup wanita jauh lebih rendah diabndingkan laki-laki. Pada penelitian Yusra (2010), hasil penelitiannya menunjukkan bahwa tidak ada hubungan antara jenis kelamin dengan kualitas hidup, laki-laki dan perempuan memiliki kemampuan yang sama dalam menyelesaikan masalah, laki-laki dan perempuan menyikapi dan berperilaku sesuai dengan yang diharapkan untuk mengelola penyakit yang dideritanya.

Berdasarkan hasil penelitian yang dilakukan pada penderita Diabetes Melitus Tipe II yang melakukan rawat jalan di Rumah Sakit Umum Ari Canti Jenis pekerjaan pada responden terbayak adalah sebagai swasta sebanyak $40 \%$, kemudian $15 \%$ orang tidak bekerja. Pekerjaan mempengaruhi aktivitas fisik seseorang, selain itu mengkonsumsi makanan yang tinggi kalori dan tidak melakukan olahraga teratur, dapat meningkatkan resiko obesitas (Hartono, 2012). Faktor pencetus yang lain dikemukakan oleh Suiraoka (2012), bahwa kemajuan teknologi dan kemapanan ekonomi membuat gaya hidup seseorang menjadi berubah. Pendapat tersebut mendukung penelitian Sunjaya (2009), diketahui bahwa orang yang memiliki aktivitas fisik yang ringan memiliki risiko 4,36 kali lebih besar untuk menderita DM.

Dari penelitian yang dilakukan pada pasien rawat jalan di Rumah Sakit Ari Canti didapatkan hasil $98 \%$ berstatus menikah, 1 orang (1\%) responden berstatus janda, 1 orang (1\%) 
responden berstatus duda. Sesuai dengan penelitian Coffman (2008), pasien DM akan mendapatkan berbagai dukungan sosial yang dapat meningkatkan kepercayaan diri. Dukungan sosial yang utama adalah dukungan dari keluarga dan dukungan yang lain didapatkan dari teman dan petugas kesehatan.

\section{Gambaran Kualitas Hidup Pasien Diabetes Melitus Tipe II}

Kuisioner pada penelitian ini diadopsi dari Kuisioner World Health Organization Quality Of Life (WHOQOL)-BREF yang berisi 26 pertanyaan, 2 pertanyaan menggambarkan kualitas hidup secara umum dan 24 pertanyaan menggambarkan 4 dimensi dari kualitas hidup.

Berdasarkan hasil penelitian yang dilakukan pada 100 responden penderita DM Tipe II yang melakukan rawat jalan di Rumah Sakit Umum Ari Canti, sebanyak $41 \%$ responden menyatakan kualitas hidupnya secara umum sedang dan sebanyak $53 \%$ responden menyatakan kesehatannya secara umum sedang. Hal ini didapatkan dari kategori skor pertanyaan pada soal nomor 1 dan 2. Kebanyakan dari responden memilih jawaban pada kualitas hidupnya pada rentang kualitas hidup sedang. Secara umum penyakit Diabetes Melitus akan mempengaruhi kesehatan tubuh penderitanya, mulai dari rambut sampai ujung kaki. Mungkin keadaan yang tergambarkan dari hasil penelitian ini dikarenakan pada saat tersebut kondisi kesehatan responden sedang baik dalam arti kadar gula darahnya berada pada level normal sehingga responden merasa puas dengan keadaan kesehatannya. (Kurniawan dkk, 2008).

Kualitas hidup responden dilihat dari dimensi kesehatan fisik, memiliki rata-rata kualitas hidup sedang. Dari hasil penelitian yang dilakukan rata-rata responden menyatakan dapat melakukan aktivitasnya sehari-hari dalam jumlah sedang, meliki ketergantungan obat-obatan dalam julah sedikit, memiliki vitalitas untuk beraktivitas dalam jumlah sedikit, melakukan mobilitas sehari-hari dalam jumlah sedang, merasa biasa-biasa dengan kualitas tidurnya, dan merasa puas dengan kemampuan sehari-hari.

Kualitas hidup pasien DM Tipe II di Rumah Sakit Umum Ari Canti jika dilihat dari dimensi psikologis memiliki rata-rata kualitas hidup yang sedang yang berarti responden menyatakan cukup menikmati hidupnya, sangat mampu berkonsentrasi, sering kali menerima penampilannya, tidak pernah merasa cemas dan depresi. Dimensi psikologis terdiri dari bodily dan appearance, perasaan negatif, perasaan positif, self-esteem, berfikir, belajar, memori, dan konsentrasi.

Jika dilihat dari dimensi hubungan sosial, penderita DM Tipe II di Rumah Sakit Umum Ari Canti memiliki rata-rata kualitas hidup yang sedang. Dari hasil penelitian yang dilakukan ratarata responden menyatakan sebagian besar responden merasa puas hubungan personal atau sosial yang dimilikinya, merasa puas dengan kehidupasn seksual; dan merasa puas dengan dukungan sosial yang diperolehnya. Dimensi hubungan sosial mencakup relasi personal, dukungan sosial dan aktivitas sosial.

Dilihat dari dimensi lingkungan, penderita DM Tipe II di Rumah Sakit Umum Ari Canti memiliki kualitas hidup yang sedang. Dari penelitian yang telah dilakukan, rata-rata responden menyatakan bahwa dirinya dapat memiliki kesempatan melakukan rekreasi dalam jumlah sedang. Dalam hal kebahagiaan, faktor lingkungan memiliki pemaknaan yang berbeda terhadap kebahagiaan yang ia rasakan dengan merasakan aman, kebersihan lingkungan, dapat memenuhi kebutuhan.

\section{SIMPULAN}

Dari hasil penilaian kuisioner yang telah dilakukan, dapat disimpulkan bahwa penilaian kualitas hidup berdasarkan 4 dimensi kualitas hidup pada penderita rawat jalan DM Tipe II yang melakukan rawat jalan di Rumah Sakit Umum Ari Canti adalah dari 4 (empat) dimensi penilaian kualitas hidup yaitu dimensi kesehatan fisik mempunyai nilai sedang, dimensi psikologis mempunyai nilai sedang, dimensi hubungan sosial mempunyai nilai sedang dan dimensi lingkungan memiliki nilai sedang.

\section{UCAPAN TERIMAKASIH}

Ucapan terimakasih kepada seluruh pihak yang sudah membantu penelitian ini sehingga bisa berjalan dengan baik khususnya Rumah Sakit Umum Ari Canti.

\section{DAFTAR PUSTAKA}

American Diabetes Association Standards of Care. 2018.

https://diabetesed.net/wpcontent/uploads/201 7/12/2018- ADA-Standards-of-Care.pdf. Diakses pada tanggal 8 Februari 2019 
Angriyani, D. 2008. Kualitas Hidup pada Orang dengan Penyakit Lupus Erythematotus (Odapus). Skripsi Fakultas Psikologi Universitas Airlangga. Tidak Dipublikasikan.

Astuti, N., Syamsiatun, N. \& Suryani, I. 2015. Faktor-faktor yang berhubungan dengan kualitas hidup pasien gagal ginjal kronik yang menjalani hemodialisa di rumah sakit umum daerah Panembahan Senopati Bantul, Jurnal Nutrisia. 17 (1) 10-16.

Azwar, Saifuddin. 2004. Metode Penelitian. Yogyakarta: Pustaka Pelajar. Chaer, Abdul.1993. Gramatika Bahasa Indonesia. Jakarta: Rineka Cipta 2003. Linguistik Umum. Jakarta: Rineka Cipta.

Coffman, M.J. 2008. Effects of tangible social support and depression on diabetes selfefficacy. Journal of Gerontological Nursing

Departemen Kesehatan RI. 2005. Pharmaceutical Care Untuk Penyakit Diabetes Mellitus. Direktorat Jendral: Direktorat Bina Farmasi Komunitas dan Klinik.

Ernawati, 2013. Penatalaksanaan Keperawatan Diabetes Melitus Terpadu. Jakarta: Penerbit Mitra Wacana Media.

Gautam, Y., Sharma, A. K., Agarwal, A. K., Bhatnagar, M. K., Trehan, R. R. (2009). A cross sectional study of $Q O L$ of diabetic patients at tertiary care hospital in Delhi.Indian Journal Community Medicine.34 (4), 346-350 http://www.ijcm.org.in/article.asp?issn=0970 0218; year $=2009$; volume $=34$; issue $=4$; spage . Diakses 10 Juni 2019

Hartono, R. 2012. Hubungan asupan serat larut (soluble dietary fiber) dan aktivitas fisik dengan kejadian diabetes melitus tipe II pasien rawat jalan di RSUD Dr. Rubini Mempawah Kalimantan Barat. http://old.fk.ub.ac.id. Diakses pada tanggal 12 Juni 2019

Herdianti, 2017, Determinan Kualitas Hidup Penderita DM Tipe 2 Di RSUD Ajjappange, Journal Endurance, 2(2), 74-80.
Hidayat, A. 2009. Metode Penelitian Keperawatan dan Tekhnik. Analisis Data. Jakarta: Salemba Medika.

Kemenkes Ri. 2018. Riset Kesehatan Dasar; RISKESDAS. Jakarta: Balitbang.

Kerner, W. and Bruckel, J. 2014. Definition, Classification and Diagnosis ofDiabetes Mellitus.Exp Clin Endocrinol Diabetes, 122(07), pp.384-386.

Khalid, W., Rozi, S., Ali, T. S., Azam, I., Mullen, M. T., Illyas, S., Nisa, Q. U., Soomro, N. \& Kamal, A. K. 2016. Quality of life after stroke in pakistan: BMC Neurology. 16(250).

Kurniawan, Y., Hana, R., dan Ida, M., 2008. Kualitas Hidup Penderita Diabetes Mellitus di Rumah Sakit Umum Cianjur, Vol. 10, No. VXIII, Halaman 86.

Lin, X., Shang, Y., Ten, S., Liu, H. \& Han, L. 2015. Relationship between perceived social support and quality of life among kidney transplant recipients, GSTF Journal of Nursing and Health Care. 3 (1) 105-110.

Melina, Dian Kusumadewi. 2011. Peran Stresor Harian, Optimesme dan Regulasi Diri terhadap Kualitas Hidup Individu dengan Diabetes Mellitu Tipe 2. PSOKOISLAMIKA.Jurnal Psikologi Islam. Vol.8. no. 1

Mabsusah. 2016. Kualitas hidup (quality of life) pasien diabetes mellitus di RSUD DR. $H$. Slamet Martodirdjo Kabupaten Pamekasan Madura [Skripsi]. Surabaya: Universitas Islam Negeri Sunan Ampel Surabaya.

Notoatmodjo, S. 2007. Promosi Kesehatan dan Ilmu Perilaku.Jakarta: Rineka Cipta.

Notoatmodjo, S. 2012, Metodelogi Penelitian Kesehatan, Edisi Revisi, Rineka Cipta, Jakarta. Indonesia.

Ozougwu, O. 2013. The pathogenesis and pathophysiology of type 1 and type 2diabetes mellitus. J. Physiol. Pathophysiol. 4(4), pp. 46-57.

PERKENI. 2015. Konsesus dan Pencegahan Diabetes Mellitus Tipe 2 Di Indonesia. Jakarta 
Putri, M. A. 2009. Kebahagiaan dan Kualitas Hidup Penduduk Jabodetabek (Studi pada Dewasa Muda Bekerja dan Tidak Bekerja) Skripsi. Depok: Fakultas Psikologi Universitas Indonesia.

Sandjaya. Esther J, Delwien. 2018. Faktor- Faktor yang Mempengaruhi Kualitas Hidup Masyarakat Karubaga District Sub District Tolikara Propinsi Papua. Jurnal Nasional Ilmu Kesehatan:Volume 1

Sekarwiri, E. 2008. Hubungan antara kualitas hidup dengan sense of community pada warga DKI jakarta yang tinggal di daerah rawan banjir. Diakses pada 10 Juni 2019

Sekarwiri, E. 2008. Hubungan antara kualitas hidup dengan sense of community pada warga DKI jakarta yang tinggal di daerah rawan banjir. Diakses pada 15 Juni

Silaban R.L. 2013. Kualitas Hidup Pasien Diabetes Mellitus di Poliklinik Endokrin RSUD Dr. Pirngadi Medan.Skripsi. Medan. Fakultas Keperawatan USU

Smelltzer \& Bare. 2002. Buku ajar keperawatan medical bedah-Brunner \& Suddarth. Jakarta: EGC

Sousa, dkk. 2016. New Measure of Diabetes Self care Agency, Diabetes Self-efficacy, dan Diabetes Self - Management for Insulintreated Individual with Type 2 Diabetes. Journal of Clinical Nursing, 18, 1305-1312

Suardana Ketut. Rasdini, Ari., Kusmarjathi, Ketut. 2015. Hubungan dukungan social keluarga dengan kualitas hidup pasien diabetes mellitus tipe II di Puskesmas Denpasar Selatan. Jurnal Jurusan Keperawatan Politeknik Kesehatan Denpasar.

Suiraoka I, P,. 2012. Penyakit degeneratif, mengenal, mencegah, mengurangi risiko 9 penyakit degeneratif. Yogyakarta: Nuha Medika.

Sunjaya, I. N. 2009. Pola konsumsi makanan tradisional Bali sebagai faktor risiko diabetes melitus tipe 2 di Tabanan. Jurnal Skala Husada

Trisnawati. 2013. Faktor Risiko Kejadian Diabetes mellitus Tipe 2 di Puskesmas Kecamatan cengkareng Jakarta Barat, Jurnal Ilmiah kesehatan Vol.5, No.1, http://lp3m.thamrin.ac.id/upload/artikel\%202 \%20vol\%205\%20no\%201_ shara.pdf, Diakses tanggal 10 Juni 2019

Utami, D. T., Karim, D \& Agrina. 2014. FaktorFaktor yang Mempengaruhi Kualitas Hidup Pasien Diabetes Mellitus dengan Ulkus Diabetikum.Universitas Riau. JOM PSIK VOL. 1

Vitaliano, P. P., Scanlan, J. M., Krenz, C., \& Fujimoto, W. 1996. Insulin and glucose: Relationship with hassless, anger and hostility in nondiabetic older adults. Psychosomatic Medicine, 58, 489-499

WHO. 2012. Scoring and Coding for the WHOQOL HIV Instruments. [Online] World Health Organization. Available at: http://www.who.int/mental_health/ publications/whoqol/en/ [Accessed 28 Februari 2019].

World Health Organization. 2018. Available at : (https://www.who.int/mediacentre/ factsheets/fs138/en/). Diakses pada tanggal 8 Februari 2019

World Health Organization, 1996. WHOQoLBREF, Introduction Administration Scoring an Generic Version of The Assessment, Field Trial Version, diakses pada 1 Maret 2019 <www.who.int $>$. 